Pena Justisia: Media Komunikasi dan Kajian Hukum
Vol. 17 No. 1, 2017, 56-65
Artikel Hasil Penelitian

\title{
Universalism Vs. Cultural Relativism dan Implementasinya dalam Hak Kebebasan Beragama Di Indonesia
}

\author{
Belardo Mega Jaya, Muhammad Rusli Arafat
}

Program Pascasarjana Fakultas Hukum Universitas Padjajaran, Indonesia

Artikel Diterima:

1 Mei 2017

Artikel Disetujui:

29 Mei 2017

Artikel Diterbitkan:

10 Juni 2017

\begin{abstract}
One of human right issue which is always debate is conflict of two different between "ideologies / perspectives" in the application of human rights on a na-tional scale, there are universalism and cultural relativism, it will make different way to human right application in countries, one of them is to application of right to religion. This research is normative. The result of this research showed that universalism put human right (HAM) as universal values as formulated in International Bills of Human Rights. Human rights have been naturally owned by an individual. This is the universal nature of those rights where human rights are a natural rights theory and apply to anyone and everywhere. These rights cannot revoke by anyone, and also cannot be trans-ferred from human to other human or regulated by the state. The State is obliged to fulfill those rights. In contrast to cultural relativism, which rejects the view of universal rights.
\end{abstract}

Keywords: Human Right, Right to Religion

\section{Abstrak}

Salah satu isu hak asasi manusia yang selalu menjadi perdebatan adalah konflik antara dua "ideologi/perspektif" yang berbeda dalam penerapan hak asasi manusia dalam skala nasional, yaitu universalisme (universalism) dan relativisme budaya (cultural relativism), hal tersebut akan menyebabkan perbedaan dalam hal penerapan hak asasi manusia di negaranegara, salah satunya dalam penerapan dalam hak kebebasan beragama (right to reli-gion). Penelitian ini adalah penelitian hukum normatif. Hasil penelitian menunjukkan bahwa Universalisme menempatkan HAM sebagai nilai-nilai universal sebagaimana dirumuskan dalam berbagai bentuk International Bills of Human Rights. Hak asasi manusia telah secara alamiah dimiliki oleh seorang individu. Inilah sifat universal dari hak-hak tersebut dimana hak asasi manusia merupakan hak kodrati (natural rights theory) dan berlaku terhadap siapa saja (everyone) dan dimana saja (everywhere). Hak-hak ini tidak dapat dicabut oleh siapa pun, dan juga tidak bisa dipindah tangankan dari manusia yang ke manusia yang lainnya atau diatur oleh negara. Negara berkewajiban pemenuhan hak-hak tersebut. Berbeda dengan relativisme budaya (cultural relativism), yang menolak pandangan adanya hak yang bersifat universal.

Kata Kunci : HAM, Hak Kebebasan Beragama 


\section{PENDAHULUAN}

Salah satu isu hak asasi manusia yang selalu menjadi perdebatan adalah konflik antara dua "ideologi/perspektif" yang berbeda dalam penerapan hak asasi manusia dalam skala nasional, yaitu universalisme (universalism) dan relativisme budaya (cultural relativism). ${ }^{1}$ Perdebatan panjang tentang universalisme dan relativisme di dalam hak asasi manusia telah membelah negaranegara Barat yang mayoritas mendukung universalisme hak asasi manusia dengan negara-negara Timur yang mengedepan-kan relativisme budaya. Hal tersebut dikarenakan terdapat perbedaan dalam konsep filosofis hak asasi manusia.

Negara-negara Barat selalu membela prioritas mereka mengenai hak asasi manusia. Bagi mereka, hak asasi manusia telah secara alamiah dimiliki oleh seorang individu dan harus diakui secara penuh dan dihormati oleh pemerintah. Bagi negara-negara Timur dan non-liberal, hak asasi manusia dianggap ada hanya dalam suatu masyarakat dan dalam suatu negara. Hak asasi manusia tidak ada sebelum adanya negara, melainkan diberikan oleh negara, dengan demikian negara dapat membatasi hak asasi manusia jika diperlukan. ${ }^{2}$ Perbedaan perspektif tersebut membuat suatu permasalahan bagi penerapan hak asasi manusia, salah satunya dalam hak beragama. Penerapan hak beragama menjadi multitafsir yang dipengaruhi oleh adanya perbedaan pandangan atau perspektif terhadap Hak tersebut.

\section{RUMUSAN MASALAH}

Berdasarkan permasalahan pada pendahuluan di atas, dirumsukan masalah kedalam rumusan masalah sebagai berikut: Pertama, Apa yang dimaksud dengan universalisme (universalism) dan relativisme budaya (cultural relativism); Kedua bagaimana penerapannya dalam hak kebebasan beragama di Indonesia.

1 Rhona K.M Smith, 2008, Hukum Hak Asasi Manusia, Yogyakarta: Pusham UII, hlm. 18.

2 Ibid., hlm. 22.

3 Halili, 2015, Hak Asasi Manusia: Dari Teori ke Pedagogi, Yogyakarta: Fakultas Ilmu Sosial Universitas Negeri, hlm.8.

4 United Nations, UN Charter, dapat diakses di www.un.org/ en/charter-united-nations/.

5 Pemikiran Hak Asasi Manusia sebagai hak yang alamiah ini berasal dari tulisan Aristoteles dalam karyanya "Nicoma-

\section{PEMBAHASAN}

\section{Pengertian Universalisme (Universalism) dan} Relativisme Budaya (Cultural Relativism)

\section{Universalisme (Universalism)}

Pandangan universal mengenai HAM artinya menempatkan HAM sebagai nilai-nilai universal sebagaimana dirumuskan dalam berbagai bentuk International Bills of Human Rights dengan tidak mempertimbangkan faktor dan konfigurasi sosial budaya serta konteks ruang dan waktu yang melekat pada masing-masing negara atau bangsa. HAM ditempatkan sebagai nilai dan norma yang melintasi yurisdiksi negara-negara. ${ }^{3}$ Pasal 55 Point (c) Piagam PBB menyatakan penghormatan universal untuk, dan pengakuan terhadap, hakhak asasi manusia dan kebebasan fundamental bagi semua tanpa perbedaan terhadap ras, jenis kelamin, bahasa, atau agama. Selanjutnya, kemudian Pasal 56 Piagam PBB menyatakan bahwa semua Anggota berjanji untuk mengambil langkah bersama atau terpisah dengan bekerjasama dengan Organisasi untuk pencapaian yang dicantumkan di dalam Pasal 55. Pasal tersebut mendalilkan bahwa hak asasi manusia bersifat universal dan negara-negara harus mengakui dan mengambil tindakan terhadap pemenuhan hakhak tersebut. ${ }^{4}$

Perspektif Barat secara umum, sebagaimana yang umum didefinisikan, termasuk di dalam instrumen hak asasi manusia PBB, hak asasi manusia dipandang sebagai hak-hak yang secara alamiah $^{5}$ telah melekat pada diri manusia sejak keberadaannya dan tanpa hak-hak tersebut manusia tidak dapat hidup sebagai manusia,"Human rights could be generally defined as those rights which are inherent in our nature and without which we can not live as human being". ${ }^{6}$ Bagi penganut paham universal, setiap orang (everyone) memiliki hak asasi dan kebebasan fundamental secara

chean Ethics", yang menguraikan suatu argumentasi yang mendukung keberadaan ketertiban moral yang bersifat alamiah, dalam Nur Asmarani, Tori Hak Asasi Manusia (HAM), Jurnal Hukum dan Masyarakat, Vol. 14, No. 1, Januari, 2015, hlm. 35.

$6 \quad$ Abu al A'la al-Mawdûdî, 1993, "Human Rights, the West and Islam," dalam Tahir Mahmood (ed.), Human Rights in Islamic Law, New Delhi: Institute of Objective Studies, hlm. 24. 


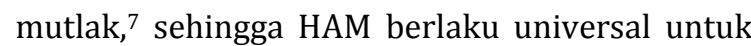
semua orang (all person) dan berlaku sama dimanapun (everywhere). ${ }^{8}$ Hal tersebut mendalilkan bahwa meskipun setiap orang terlahir dengan warna kulit, jenis kelamin, bahasa, dan berada dalam budaya dan kewarganegaraan yang berbeda-beda, ia tetap mempunyai atau memiliki hak-hak tersebut.

Menurut Universalisme, Hak asasi manusia adalah hak-hak yang dimiliki manusia bukan karena diberikan kepadanya oleh masyarakat atau berdasarkan hukum positif, melainkan sematamata berdasarkan martabatnya sebagai manusia. ${ }^{9}$ Rhoda E. Howard, seorang sosiolog, pendukung paham universalisme menyatakan bahwa hak asasi manusia adalah hak yang dimiliki manusia karena ia adalah manusia. ${ }^{10}$ Hak-hak ini dimiliki oleh manusia semata-mata karena mereka adalah manusia, bukan karena mereka adalah warga negara dalam suatu negara. ${ }^{11}$ Inilah sifat universal dari hak-hak tersebut dimana hak asasi manusia merupakan hak kodrati (natural rights theory). Berkenaan dengan teori hak kodrati ini, John Locke, dalam bukunya The Second Treatise of Civil Government and a Letter Concerning Toleration, mengajukan sebuah postulasi pemikiran bahwa semua individu dikaruniai oleh alam suatu hak yang melekat atas hidup, kebebasan dan kepemilikan, yang merupakan milik mereka sendiri dan tidak dapat dicabut atau diambil oleh negara. Melalui suatu 'kontrak sosial' perlindungan atas hak yang tidak dapat dicabut ini diserahkan

7 Rhona K.M Smith, 2010, Texts and Materials on International Human Right, Second edition, Routledge, London and Newyork, hlm. 36.

8 Henry J. Steiner dan Phillip Aston, 2000, International $\mathrm{Hu}$ man Rights in Context, Law, Politics, Moral, Oxford University Press, New York, hlm. 366.

9 Jack Donnelly, 2003, Universal Human Rights in Theory and Practice, Ithaca and London: Cornell University Press. hlm. 7-21. Lihat juga Maurice Cranston, 1973, What are Human Rights?, New York: Taplinger, hlm. 70.

10 Rhoda E. Howard, 2000, Penjelajahan Dalih Relativisme Budaya (terjemahan). Jakarta: PT. Pustaka Utama Grafiti, hlm.1.

11 RP. Claude dan Burns H. Wston, 1992, Human Rights in the World Community, University of Pennsylvania Press, Philadelphia, hlm. 14-30.

12 John Locke, 1964, The Second Treatise of Civil Government and a Letter Concerning Toleration, disunting oleh J.W. Gough, Oxford, Blackwell, sebagaimana dikutip oleh Parluhutan Siregar, Etika Politik Global: Isu Hak-Hak Asasi Manusia, Jurnal Medan Agama, Volume 6, Nomor 1, 2014, hlm. 2, dapat diakses secara online di http://jurnal medanagama.org/index.php/medag/article/view/24. kepada negara. ${ }^{12}$ Hak-hak ini tidak dapat dicabut oleh siapa pun, dan juga tidak bisa dipindah tangankan dari manusia yang ke manusia yang lainnya. ${ }^{13}$ John Locke menyatakan bahwa, negara hadir justru untuk melaya ni kepentingan dan pemenuhan hak-hak tersebut. ${ }^{14}$

\section{Relativisme Budaya (Cultural Relativism)}

Isu relativisme budaya baru muncul menjelang berakhirnya Perang Dingin sebagai respon terhadap klaim universal dari gagasan HAM Internasional. Gagasan tentang relativisme budaya mendalilkan bahwa kebudayaan merupakan satu-satunya sumber keabsahan hak atau kaidah moral. Semua kebudayaan mempunyai hak hidup serta martabat yang sama yang harus dihormati ${ }^{15}$, dengan demikian HAM harus diletakkan dalam konteks budaya tertentu di masingmasing negara. Dengan dalil tersebut relativisme budaya menyatakan bahwa "there is no such thing as universal rights" yang merupakan suatu penolakan terhadap pandangan adanya hak yang bersifat universal apalagi bila hak tersebut didominasi oleh suatu budaya tertentu. ${ }^{16}$

Pandangan ini kemudian berkembang pada abad ke-18 setelah Johann Gottfried von Herder mengklaim bahwa tiap-tiap bangsa memiliki keunikan sendiri-sendiri yang mengakibatkan nilai universal adalah suatu kebohongan, yang ada hanyalah bersifat kewilayahan dan ketaksengajaan (contingent). ${ }^{17}$ Relativisme berpandangan bahwa perlindungan hak asasi

13 Wolhoff, 1995, Pengantar Imu Hukum Tata Negara Repubik Indonesia, Jakarta: Timun Mas, hlm. 120.

14 John Locke, Two treaties of Goverment, In the Former, The False Principles and Foundation of Sir Robert Filmer, and His Followers, Are Detected and Overthrown: The Latter, Is an Essay Concerning the Original, Extent, and End, of Civil Government, A new Edition, Printed for Thomas Tegg, London, 1823, hlm. 16 dapat diakses secara online di socserv2.socsci.mcmaster.ca/econ/ugcm/3ll3/locke/gov ernment.pdf.

15 Jack Donnelly, Op. Cit., hlm. 89-93.

16 Todung Mulya Lubis, 1993, In search of Human Rights Legal-Political Dilemmas of Indonesia's New Order, 19661990, Jakarta: Gramedia, hlm. 18-19 dalam Andrey Sujatmoko, 2009, Training Metode Pendekatan Pengajaran, Penelitian, Penulisan Disertasi dan Pencarian Bahan Hukum HAM Bagi Dosen-Dosen Hukum HAM, Sejarah, Teori, Prinsip dan Kontroversi HAM, Yogyakarta, 12 - 13 Maret 2009, hlm. 17.

17 Pranoto Iskandar, 2010, Hukum HAM Internasional, Sebuah Pengantar Kontekstual, IMR Press, Malang, 156 
manusia yang universal merupakan bentuk intervensi budaya (cultural imperialism) dari bangsa Barat. Universalisme tersebut merusak keragaman budaya dan bentuk hegemonisasi budaya (cultural hegemonisation) menuju satu dunia modern. ${ }^{18}$ Menurut Howard, relativisme budaya merupakan konsepsi absolutisme budaya yang menyatakan bahwa budaya suatu masyarakat adalah nilai etis tertinggi, HAM tidak dapat didukung jika pelaksanaannya mengakibatkan perubahan di dalam sebuah budaya itu sendiri, maka pelaksanan HAM tersebut harus disesuaikan pada budaya di masing-masing negara. ${ }^{19}$ Asosiasi Antropologi Amerika (American Anthropologial Association) mengeluarkan suatu pernyataan di hadapan Komisi HAM PBB ketika Komisi ini sedang mempersiapkan rancangan Deklarasi Universal HAM yang menginginkan perlunya dipikirkan, dalam rangka menyusun suatu deklarasi, untuk menyelesaikan masalah-masalah seperti: bagaimana Deklarasi nantinya dapat berlaku bagi seluruh manusia dan tidak merupakan suatu pernyataan mengenai hak-hak (statement of rights) yang hanya menggambarkan nilai-nilai yang lazim terdapat di negaranegara Eropa Barat dan Amerika. ${ }^{20}$

Gagasan bahwa hak asasi manusia terikat dengan konteks budaya juga diusung oleh negara-negara berkembang dan negara-negara Islam. Gagasan ini begitu mengemuka pada dasawarsa 1990-an terutama menjelang Konferensi Dunia Hak Asasi Manusia di Wina disuarakan oleh para pemimpin dan cendikiawan negara-negara tersebut. Para pemimpin negaranegara di kawasan Lembah Pasifik Barat, misalnya, mengajukan klaim bahwa apa yang mereka sebut sebagai "nilai-nilai Asia" (Asian Values) lebih relevan untuk kemajuan di kawasan ini, dibandingkan "nilai-nilai Barat" (Western values), seperti hak asasi manusia dan demokrasi

\footnotetext{
Ibid., hlm. 367.

Rhona K.M Smith, Njäl Høstmælingen, dkk, Op.Ct., hlm. 20.

Todung Mulya Lubis, Op. Cit., hlm. 19-20.

Rhona K.M Smith, Njäl Høstmælingen, dkk, Op.Cit., hlm. 21.

22 Miriam Budiardjo, "HAM dan Tap MPRS. No.XXV", Majalah Forum Keadilan, 9 April 2000, hlm. 43. Sebagaimana dikutip dalam Ikhwan Matondang, Op.Cit., hlm. 212.

23 Soetandyo Wignjosoebroto, "Hubungan Negara dan Masyarakat dalam Konteks Hak Asasi Manusia; Sebuah Tinjauan Historik dari Relativisme Budaya - Politik". Makalah disampaikan pada Seminar Pembangunan Hu-
}

yang dinilai tidak begitu urgent bagi bangsabangsa Asia. ${ }^{21}$ Pada Konferensi Dunia tentang Hak Asasi Manusia di Wina tahun 1993, atas desakan negara-negara berkembang, disepakati adanya kelonggaran-kelonggaran tertentu yang diberikan PBB dalam pelaksanaan hak asasi manusia. Disebutkan juga bahwa kekhususan-kekhususan nasional, regional, serta berbagai latar sejarah, budaya, dan agama harus selalu dipertimbangkan tanpa mengurangi tugas semua negara untuk memajukan semua hak asasi manusia (Pasal 5 Deklarasi Wina 1993).22

\section{Universalisme (Universalism) Dan Relativisme Budaya (Cultural Relativism) Penerapannya Dalam Hak Kebebasan Beragama Di Indonesia}

\section{Perspektif Ham Di Regional Asean}

Menghadapi persoalan universalisme dan relativisme ini, banyak negara di kawasan-kawasan regional mencoba mendefinisikan ulang hak asasi manusia. Di kawasan Asean misalnya, pernah dideklarasikan (Bangkok Declaration) suatu pernyataan mengenai "kewajiban-kewajiban dasar bagi masyarakat dan pemerintah di negara-negara ASEAN". ${ }^{23}$ Dalam Deklarasi Bangkok dinyatakan bahwa di samping HAM bersifat universal haruslah dipahami dengan memperhatikan pentingnya kekhasan regional dan nasional dan beragam latar belakang historis, budaya dan keagamaan. ${ }^{24}$ Walaupun Deklarasi Bangkok tersebut menyebutkan HAM sebagai suatu konsep yang "universal" namun wakil negara-negara Asia pada umumnya berpendapat bahwa konsep yang HAM tidak "universal", melainkan hasil kebudayaan politik Barat, dan pada dasarnya kurang sesuai untuk diterapkan begitu saja di negara-negara Timur, yang tengah menghadapi tantangan-tantangan ekonomi, sosial, dan politik yang sangat berbeda dengan apa yang dialami oleh negara-negara Barat. Oleh karena

kum Nasional VIII diselenggarakan oleh BPHN DepKeh \& HAM. Denpasar, 2003, hlm. 4 sebagaimana dikutip dalam Marzuki, The Perspectives of the Constitutional Court on Human Rights, Jurnal Yudisial, Vol. 6 No. 3, Fakultas Hukum Universitas Islam Indonesia, Desember 2013: 189 - 206, hlm 192.

24 Association of Southeast Asian Nations, The Asean Declaration (Bangkok Declaration), dapat diakses di agreement.asean.org/media/download/2014011715415 9.pdf. Lihat juga Iskandar, Op.Cit., hlm. 159. 
itu, Deklarasi Bangkok menekankan pentingnya latar belakang sejarah, kebudayaan, dan agama dalam memahami dan melaksanakan konsep hak-hak asasi manusia. ${ }^{25}$

Menurut kebudayaan politik Asia, salah satunya Indonesia, yang senantiasa mereka utamakan adalah kepentingan masyarakat secara keseluruhan, bukan hak individu. Keharmonian sangat dihargai, sedangkan konflik dianggap sebagai sumber perpecahan dan hal-hal buruk lainnya. Jika yang diutamakan hanya hak individu saja, dikhawatirkan pemerintah tidak dapat menjamin keharmonian masyarakat. ${ }^{26}$ HAM melekat secara perseorangan, tetapi manusia tidak dapat menghindar dari kodrat sebagai makhluk sosial. Karena itu, sesuai dengan kodrat manusia sebagai makhluk individu dan sosial, maka harus dijaga keseimbangan dan keselarasan antara kebebasan individu dan tanggungjawab sosial, pelaksanaan nilai-nilai HAM merupakan wewenang dan tanggungjawab pemerintah atau negara bersangkutan. ${ }^{27}$ Kemudian pada tanggal 19 November 2012, ASEAN kembali menetapkan ASEAN Human Rights Declaration. ${ }^{28}$ Deklarasi tersebut menegaskan kembali komitmen ASEAN terhadap hak asasi manusia. ${ }^{29}$ Menurut deklarasi tersebut, penerapan HAM di tingkat regional Asia harus tetap mempertimbangkan karakteristik, perbedaan sejarah, budaya, dan agama di masing-masing negara, serta menjaga keseimbangan hak dan kewajiban. ${ }^{30}$

\section{Perspektif HAM Di Indonesia}

Tuntutan yang dikehendaki pada saat era reformasi adalah penguatan Hak Asasi Manusia (HAM) dan demokrasi. Dua tuntutan itulah yang menjadi urgensi dalam kehidupan berbangsa,

25 Marzuki, Op.Cit., hlm 192-193.

26 Haris Munandar, Pembangunan Politik, Situasi Global, dan Hak Asasi di Indonesia, Gramedia Pustaka Utama, Jakarta, 1994, hlm. 453. Sebagaimana dikutip dalam Marzuki, Op.Cit., hlm 193.

27 B.J. Habibie, Detik-Detik yang Menentukan: Jalan Panjang Indonesia Menuju Demokrasi, THC. Mandiri, Jakarta, 2006, hlm. 474-479. Sebagaimana dikutip dalam Marzuki, Loc.Cit.

28 E Book Oak Fondation, Kewajiban Negara dalam Penanganan Kasus-Kasus Pelanggaran HAM dan Pelanggaran HAM yang Berat di Indonesia, Buku Panduan Mengukur Kewajiban Negara, The Commission for Disappearances and Victims of Violence, Jakarta, Mei 2014, hlml. 18. bernegara dan bermasyarakat di Indonesia. ${ }^{31}$ Negara Republik Indonesia sebagai negara hukum sangat mengakui dan menjunjung tinggi Hak Asasi Manusia dan kebebasan dasar manusia yang harus dilindungi dan harus dihormati demi peningkatan martabat kemanusiaan, kesejahteraan, dan kecerdasan serta keadilan. ${ }^{32}$ Oleh karena itu Indonesia merupakan negara yang mendukung ketentuan-ketentuan internasional yang berkaitan dengan HAM seperti Deklarasi Universal Hak Asasi Manusia/DUHAM (Declaration of Human Right), Kovenan Internasional Hak-Hak Sipil dan Politik (International Covenant on Civil and Political Rights), dan lain-lain. Insturmen-instrumen tersebut merupakan suatu pengakuan hak asasi manusia yang universal, yang melakat kepada setiap manusia secara alamiah. $^{33}$

Sebagai implementasinya, kebebasan beragama dijamin dalam Undang-Undang Dasar Tahun 1945, yaitu dalam Pasal 28E dan 29. Pasal 28E menyatakan bahwa "setiap orang bebas memeluk agama dan beribadat menurut agamanya, meyakini kepercayaan, menyatakan pikiran dan sikap sesuai dengan hati nuraninya", sedangkan Pasal 29 ayat (1) menyatakan "Negara berdasarkan atas Ketuhanan Yang Maha Esa, sehingga negara menjamin kemerdekaan tiap-tiap penduduk untuk memeluk agamanya masing-masing dan untuk beribadat menurut agamanya dan kepercayaannya itu". UUD Tahun 1945, menentukan bahwa hak kebebasan beragama bukan pemberian negara atau bukan pemberian golongan melainkan berdasarkan keyakinan, hingga tidak dapat dipaksakan dan memang agama dan kepercayaan terhadap Tuhan Yang Maha Esa itu sendiri tidak memaksakan setiap manusia untuk

29 Preamble ASEAN Human Rights Declaration, dapat diakses di http://asean.org/asean/asean-charter/.

30 Wahyudi Djafar, dkk, Memperkuat Perlindungan Hak Asasi Manusia di ASEAN, International NGO Forum on Indonesia Development (INFID), Desember 2014, hlm 25-26.

31 Ahmad Muladi, Politik Hukum, Akademia Permata, Jakarta, 2014, hlm. 37.

32 Laurensius Arliman S, Penyelesaian Konflik Antar Umat Beragama (Studi Pada Komnas HAM Perwakilan Sumatera Barat, Padjadjaran Jurnal Ilmu Hukum, e-ISSN 2460-1543, Vol. 2, Nomor, Tahun 2015, hlm. 1. Lihat juga Laurensius Arliman S., Komnas HAM dan Perlindungan Anak Pelaku Tindak Pidana, Deepublish, Yogyakarta, 2015, hlm. 3.

33 Al Khanif, Hukum dan Kebebasan beragama di Indonesia, LaksBang Mediatama, Yogyakarta, 2010, hlm. 81. 
61 Pena Justisia: Media Komunikasi dan Kajian Hukum

Vol. 17, No. 2, 2017

memeluk dan menganutnya. ${ }^{34}$

Indonesia kemudian menetapkan peraturan perundang-undangan mengenai hak asasi manusia, yaitu Undang-Undang Nomor 39 Tahun 1999 tentang Hak Asasi Manusia dan UndangUndang Nomor 26 Tahun 2000 tentang Pengadilan Hak Asasi Manusia tampaknya berusaha mengakomodasi berbagai pemikiran hak asasi manusia yang berkembang, baik yang bersumber dari hukum internasional, mau pun dari tradisi agama dan budaya yang hidup di Indonesia. ${ }^{35}$

Dalam penerapannya, HAM di Indonesia dipahami sebagai nilai, konsep dan norma yang hidup dan berkembang di masyarakat, keberlakuan hak asasi manusia di Indonesia disesuaikan dengan sejarah dan budaya yang berlaku di Indonesia. Kebudayaan tersebut mempunyai hak hidup serta martabat yang sama yang harus dihormati, ${ }^{36}$ sehingga dalam pelaksanaan HAM, Indonesia juga berlandaskan kepada nilai-nilai, sejarah, dan budaya yang berlaku di Indonesia. Salah satunya adalah mengenai hak dalam kebebasan beragama (right to religion). Dalam penjelasan umum Pasal 1 Penetapan Presiden Republik Indonesia Nomor 1/PNPS/1965 yang kemudian melalui Undang-Undang Nomor 5 Tahun 1959 Penetapan Presiden tersebut diubah menjadi Undang-Undang No. 1/PNPS/1965 tentang Pencegahan Penyalahgunaan dan/atau Penodaan Agama, menjelaskan bahwa agama yang diakui di Indonesia terdiri dari 6 (enam) agama, yaitu: Islam, Kristen Protestan, Katolik, Budha, Hindu, dan Konghuchu (Confusius). ${ }^{37}$

Pasal 1 aturan tersebut menyatakan bahwa setiap orang dilarang dengan sengaja di muka umum menceritakan, menganjurkan atau mengusahakan dukungan umum, untuk melakukan penafsiran tentang sesuatu agama yang dianut di Indonesia atau melakukan kegiatan-kegiatan keagamaan yang menyerupai kegiatan-kegiatan keagamaan dari agama itu, penafsiran dan kegiatan mana menyimpang dari pokok-pokok ajaran agama itu. Kemudian Pasal 3 menyatakan

34 CST. Kansil dan Christine S.T. Kansil, Sekitar HAM Dewasa Ini, Djambatan, Jakarta, 2003, hlm. 30.

35 Ikhwan Matondang, Universalitas dan Relativitas HAM, Jurnal Miqot, Vol. XXXII No. 2 Juli-Desember 2008, Fakultas Ushuluddin IAIN Imam Bonjol, Padang, hlm. 212.

36 Jack Donnelly, Op. Cit., hlm. 89-93. bahwa "Terhadap orang, organisasi atau aliran kepercayaan, mereka masih terus melanggar ketentuan dalam Pasal 1, maka orang, penganut, anggota dan/atau anggota pengurus organisasi yang bersangkutan dari aliran itu dipidana dengan pidana penjara selama-lamanya lima tahun". 38

Hal tersebut tentunya tidak sesuai dengan ketentuan Pasal 18 DUHAM, yang menyatakan bahwa:

"Setiap orang berhak atas kebebasan pikiran, hati nurani dan agama; dalam hal ini termasuk kebebasan berganti agama atau kepercayaan, dengan kebebasan untuk menyatakan agama atau kepercayaan dengan cara mengajarkannya, melakukannya, beribadat dan menta-atinya, baik sendiri maupun bersama-sama dengan orang lain, di muka umum maupun sendiri.

Selain itu, pembatasan terhadap keyakinan beragama tersebut tidak sesuai dengan Pasal 18 Kovenan Internasional Hak-Hak Sipil dan Politik yang menyatakan bahwa :

"Setiap orang berhak atas kebebasan berfikir, berkeyakinan dan beragama, Tidak seorang pun boleh dipaksa sehingga menggangu kebebasannya untuk menganut atau menerima suatu agama atau kepercayaan sesuai dengan pilihannya".

Hak kebebasan beragama dan berkeyakinan tersebut dengan demikian terbagi menjadi dua unsur yang berbeda, yakni forum internum dan forum externum. Forum internum merupakan kebebasan dalm memilih keyakinan atau agama sesuai dengan hati nurani manusia, sedangkan forum eksternum merupakan hak kebebasan dalam berprilaku keagamaan yang berasal dari ajaran agama dan keyakinan yang dianut oleh manusia, yaitu beribadah, menulis dan menyebarkan ajaran agama, mendirikan perkumpulan dan organisasi keagamaan, pembangunan sarana ibadah, hari libur agama, berdiskusi agama, dan lain-lain. ${ }^{39}$

37 Laurensius Arliman S, Op.Cit., hlm. 381. Lihat juga Penjelasan Pasal 1 Undang-Undang No. 1/PNPS/1965 tentang Pencegahan Penyalahgunaan dan/atau Penodaan Agama.

38 Undang-Undang No. 1/PNPS/1965 tentang Pencegahan Penyalahgunaan dan/atau Penodaan Agama.

39 Al Khanif, Op.Cit., hlm. 110. 
Berkaitan dengan hal tersebut, pihak-pihak yang tidak setuju terhadap aturan yang ditetapkan dalam Undang-Undang No. 1/PNPS/1965 tentang Pencegahan Penyalahgunaan dan/atau Penodaan Agama mengajukan uji materiil (judicial review) terhadap aturan-aturan tersebut. Para pemohon mendalilkan bahwa pasal-pasal yang ditetapkan dalam Undang-Undang No. 1/PNPS/1965 tentang Pencegahan Penyalahgunaan dan/atau Penodaan Agama di atas telah menyebabkan kerugian konstitusional para pemohon karena menimbulkan diskriminasi agama terhadap selain enam agama yang diakui di Indonesia yang mana bertentangan dengan prinsip hak asasi manusia dalam kebebasan beragama sebagaimana diatur dalam Deklarasi Universal Hak Asasi Manusia (DUHAM), Kovenan Internasional Hak-hak Sipil dan Politik dan instrumen hukum internasional lainnya, serta melanggar ketentuan UUD 1945.40 Majelis Hakim menolak dalil para pemohon tersebut. Majelis Hakim menyatakan bahwa UndangUndang Pencegahan Penodaan Agama tidak sedikitpun mematikan kemajemukan agama yang ada dan tumbuh di Indonesia, karena semua penganut agama mendapat pengakuan dan jaminan perlindungan yang sama. ${ }^{41}$

Penulisan dan pengakuan enam agama disebabkan karena 6 macam Agama ini adalah agama-agama yang dipeluk hampir seluruh penduduk Indonesia pada saat itu. Hal ini dapat dibuktikan dalam sejarah perkembangan agamaagama di Indonesia, karena 6 macam agama ini adalah agama-agama yang dipeluk hampir seluruh penduduk Indonesia. ${ }^{42}$ Ketentuan tersebut dapat dilihat dalam Penjelasan Pasal 1 Undang-Undang No. 1/PNPS/1965 tentang Pencegahan Penyalahgunaan dan/atau Penodaan Agama, yang menyatakan bahwa tidak berarti agama-agama lain yang tidak termasuk dalam 6 macam agama yang telah diakui, misalnya: Yahudi, Zarasustrian, Shinto, Taoism, Kejawen (keyakinan mistis dari Jawa),

40 Putusan Mahkamah Konstitusi Nomor 140/PUU-VII/2009 tentang Pengujian UU No. 1 Tahun 1965 tentang Penyalahgunaan dan/atau Penodaan Agama, dapat diakses di http://www.mahkamahkonstitusi.go.id/.

41 Kemenkumhan RI, Ringkasan Putusan Mahkamah Konstitusi Nomor 140/PUU-VII/2009 tentang Pengujian UU No. 1 Tahun 1965 tentang Penyalahgunaan dan/atau Penodaan Agama, Media Publikasi Peraturan Perundang-Undangan dan Informasi Hukum, dapat diakses secara online di
Sunda Wiwitan, dan kepercayaan lokal lainnya dilarang di Indonesia. Mereka mendapat jaminan penuh dan perlindungan hukum dari Pemerintah Indonesia seperti yang diberikan oleh pasal 29 ayat (2) Undang-Undang Dasar 1945.43

Perlindungan tersebut juga dijamin dalam Undang-Undang Nomor 39 Tahun 1999 tentang HAM. Pasal 4 Undang-Undang Nomor 39 Tahun 1999 tentang HAM menyatakan bahwa: "hak beragama, adalah hak asasi manusia yang tidak dapat dikurangi dalam keadaan apapun dan oleh siapapun", kemudian Pasal 22 menyatakan bahwa "setiap orang bebas memeluk agamanya masingmasing dan untuk beribadat menurut agamanya dan kepercayaannya itu, dimana negara menjamin kemerdekaan setiap orang memeluk agamanya masing-masing dan untuk beribadat menurut agamanya dan kepercayaannya itu".

Dapat dilihat juga bahwa UUD 1945 tidak menentukan agama dan kepercayaan apa saja yang diakui secara sah, bahkan peraturan perundang-undangan yang ada di bawahnya juga tidak menyebutkan agama dan kepercayaan yang diakui. Oleh karena itu, tidak ada pembatasan terhadap hak untuk memilih agama dan keyakinan, setiap orang bebas menentukan keyakin dan agamanya, semua agama dan aliran kepercayaan yang dianut masyarakat Indonesia diakui dan disahkan bahkan mendapatkan suatu perlindungan hukum dari Pemerintah Indonesia. Pembatasan yang dimaksud dalam Pasal 1 Undang-Undang No. 1/PNPS/1965 tentang Pencegahan Penyalahgunaan dan/atau Penodaan Agama adalah pembatasan dalam hal penerapan dari keyakinan dan agama yang dipilih, seperti menceritakan, menganjurkan atau mengusahakan dukungan umum, untuk melakukan penafsiran, mendirikan perkumpulan dan segala kegiatan yang berkaitan dengan keagamaan yang menyerupai kegiatan-kegiatan keagamaan dari agama itu. Majelis Hakim menyatakan bahwa dalil pemohon

http://ditjenpp.kemenkumham.go.id/harmonisasirpp/62-data-perkembangan-litigasi/486-putusanmahkamah-konstitusi-terhadap-uu-pencegahanpenyalahgunaan-danatau-penodaan-agama.html.

42 Penjelasan Pasal 1 Undang-Undang No. 1/PNPS/1965 tentang Pencegahan Penyalahgunaan dan/atau Penodaan Agama.

43 Ibid. 
yang menyatakan negara tidak berhak melakukan intervensi terhadap kebebasan beragama tidaklah tepat, karena tindakan tersebut merupakan suatu upaya pemerintah untuk memelihara keamanan dan ketertiban masyarakat umum yang terganggu karena adanya pertentangan dalam masyarakat yang terjadi akibat penyebaran paham keagamaan yang dianggap oleh sebagian masyarakat menyimpang. ${ }^{44}$

Mahkamah menilai rumusan Pasal 1 Undang-Undang Pencegahan Penodaan Agama yang memberikan larangan kepada setiap orang untuk mempublikasikan penafsiran berbeda dari agama yang dianut di Indonesia adalah bentuk dari tindakan pencegahan (preventive action) dari kemungkinan terjadinya konflik horizontal di antara masyarakat Indonesia. Mahkamah memahami bahwa agama merupakan perihal yang sakral yang amat sensitif bagi kebanyakan orang. Keberadaan agama, bukan saja sebagai keabsolutan hubungan transenden pribadi (individu) melainkan telah menjadi sebuah modal sosial yang berperan besar dalam sendi-sendi kemasyarakatan. ${ }^{45}$ Larangan tersebut adalah pembatasan dalam $f_{0}$ rum eksternum, yaitu forum yang dapat dibatasi karena unsur ini yang sangat berpotensi bersinggungan dengan hak dan kebebasan beragama yang dimiliki oleh orang lain dan bisa menimbulkan gangguan terhadap ketertiban dan keamanan masyarakat, berbeda dengan forum internum yang merupakan kebebasan mutlak atau kebebasan yang tidak bisa dibatasi (non-derogable rights), hal ini dikarenakan forum internum bersentuhan langsung dengan keyakinan hati dan kecenderungan pikiran, oleh karena itu tidak mungkin pikiran dapat diambil dan dibatasi. ${ }^{46}$

Hal tersebut diatur pada Pasal 29 ayat (2) Deklarasi Universal Hak Asasi Manusia yang menyatakan bahwa dalam menjalankan hak-hak dan

44 Putusan Mahkamah Konstitusi Nomor 140/PUU-VII/2009 tentang Pengujian UU No. 1 Tahun 1965 tentang Penyalahgunaan dan/atau Penodaan Agama. Lihat juga Harian Republika, "Solusi Kemelut Ahmadiyah", Jumat, 15 Agustus 2008, hlm. 27. Sebagaimana dikutip oleh Sodikin, Hukum dan Hak Kebebasan Beragama, Jurnal Cita Hukum, ISSN: 2356-1440, VOL. I NO. 2, Fakultas Syariah dan Hukum UIN Syarif Hidayatullah, Jakarta, Desember 2013, hlm. 182, dapat diakses di journal.uinjkt.ac.id/index.php/citahukum/ article/view/2989.

45 Ibid.

46 Tore Lindholm, W. Cole Durham, Jr. Bahia G. Tahzib Lie, Facilitating Freedom of Religion or Belief: A Desbook, kebebasan-kebebasannya, setiap orang harus tunduk hanya pada pembatasan-pembatasan yang ditetapkan oleh undang-undang yang tujuannya semata-mata untuk menjamin pengakuan serta penghormatan yang tepat terhadap hak-hak dan kebebasan-kebebasan orang lain, dan untuk memenuhi syarat-syarat yang adil dalam hal kesusilaan, ketertiban dan kesejahteraan umum dalam suatu masyarakat yang demokratis. ${ }^{47}$ Selain itu diatur juga pada Pasal 18 ayat (3) Kovenan Internasional Hak-Hak Sipil dan Politik yang menyatakan bahwa Kebebasan pada forum eksternum hanya dapat dikenai pembatasan-pembatasan yang ditentukan oleh hukum dan yang diperlukan untuk melindungi keselamatan, ketertiban, kesehatan, atau kesusilaan umum, atau hakhak dan kebebasan-kebebasan mendasar milik orang lain. ${ }^{48}$ Dengan pertimbangan-pertimbangan tersebut, Majelis Hakim Mahkamah Konstitusi, dalam putusannya Menyatakan menolak permohonan para Pemohon untuk seluruhnya. ${ }^{49}$

Dengan demikian, Indonesia adalah negara yang menggunakan paradigma relativisme budaya (cultural relativism) dalam penerapan hak kebebasan berkeyakinan dan beragama, dimana pada penerapan hak hak asasi manusia harus disesuaikan pada sejarah, agama, dan nilai-nilai budaya yang berlaku di Indonesia. Hak beragama sebagai hak individu adalah hak asasi yang melekat dalam setiap diri manusia semenjak ia lahir, namun dalam konteks berbangsa dan bernegara, hak beragama juga telah menjadi sebuah hak kolektif masyarakat untuk dapat dengan tenteram dan aman menjalankan ajaran agamanya tanpa merasa terganggu dari pihak lain, oleh karena itu, hak beragama dalam konteks hak asasi individu tidak dapat dipisahkan dari hak beragama dalam konteks hak asasi komunal. Pembatasan mengenai nilai-nilai aga-

Martinus Nijhoff Publisher, Leiden, 2004, sebagaimana diterjemahkan oleh Rafael Edy Bosko, dkk, Kebebasan Beragama atau Berkeyakinan: Sejauk Mana? Sebuah Referensi tentang Prinsip-Prinsip dan Praktik, Kanisius, Yogyakarta, 2010, hlm. 203.

47 Pasal 29 ayat (2) Deklarasi Universal Hak Asasi Manusia.

48 Pasal 18 ayat (3) Kovenan Internasional Hak-Hak Sipil dan Politik.

49 Putusan Mahkamah Konstitusi Nomor 140/PUU-VII/2009 tentang Pengujian UU No. 1 Tahun 1965 tentang Penyalahgunaan dan/atau Penodaan Agama. 
ma sebagai nilai-nilai komunal (communal values) masyarakat adalah pembatasan yang sah menurut konstitusi. Hal tersebut bertujuan untuk mewujudkan kehidupan berbangsa dan bernegara yang lebih baik (the best life possible). ${ }^{50}$

Tradisi keagamaan di Indonesia memang memiliki kekhasan dan keunikan yang memang tidak dapat diintervensi oleh negara lain, selain memberikan hak kebebasan beragama, negara juga berhak memberikan pengaturan dan pembatasan atas kebebasan beragama demi kepentingan umum, yakni demi terciptanya ketertiban masyarakat umum. ${ }^{51}$ Penghormatan negara Indonesia atas berbagai konvensi serta perangkat hukum internasional termasuk hak asasi manusia haruslah tetap berdasarkan pada sejarah, budaya, falsafah dan konstitusi Negara Kesatuan Republik Indonesia. Elemen inilah yang merupakan salah satu elemen yang menandakan perbedaan pokok antara negara hukum Indonesia dengan negara hukum Barat. Inilah yang menjadi ciri khas kebebasan beragama menurut perspektif hukum Indonesia yang berbeda dengan norma universal sebagaimana diatur dalam Deklarasi Universal Hak Asasi Manusia dan Kovenan Internasional tentang Hak Sipil dan Politik. ${ }^{52}$

\section{PENUTUP}

Berdasarkan Uraian tersebut dapat disimpulkan bahwa terdapat perbedaan dalam konsep filosofis hak asasi manusia, maka muncul dua ideologi/pandangan yang berbeda terhadap konsep Hak Asasi Manusia yaitu universalisme (universalism) dan relativisme budaya (cultural relativism). Universalisme menempatkan HAM sebagai nilai-nilai universal sebagaimana dirumuskan dalam berbagai bentuk International Bills of Human Rights. Hak asasi manusia telah secara alamiah dimiliki oleh seorang individu. Inilah sifat universal dari hak-hak tersebut dimana hak asasi manusia merupakan hak kodrati (natural rights theory). Hak-hak ini tidak dapat dicabut oleh siapa pun, dan juga tidak bisa dipindah tangankan dari manusia yang ke manusia yang lainnya. Negara berkewajiban pemenuhan hak-hak tersebut. Berbeda dengan relativisme

50 Ibid. Vide Putusan Mahkamah Konstitusi Nomor 012016019/PUU-IV/2006. budaya (cultural relativism), yang menolak pandangan adanya hak yang bersifat universal. HAM harus dan diletakkan dalam konteks budaya tertentu di masing-masing negara. Kebudayaan merupakan satu-satunya sumber keabsahan hak atau kaidah moral. Semua kebudayaan mempunyai hak hidup serta martabat yang sama yang harus dihormati, maka penerapan HAM harus tetap mempertimbangkan karakteristik, perbedaan sejarah, budaya, dan agama di masingmasing negara.

Di Indonesia, penerapan dan pelaksanaan HAM harus disesuaikan pada nilai-nilai dan budaya yang berlaku di Indonesia (relativisme budaya). Penghormatan negara Indonesia atas berbagai konvensi serta perangkat hukum internasional termasuk hak asasi manusia haruslah tetap berdasarkan pada sejarah, budaya, falsafah dan konstitusi Negara Kesatuan Republik Indonesia. Contohnya pada penerapan hak kebebasan berfikir, berkeyakinan dan beragama. Dimana Pemerintah memberikan pengaturan hukum yang diperlukan untuk melindungi keselamatan, ketertiban, kesehatan, atau kesusilaan umum, atau hak-hak dan kebebasan-kebebasan mendasar milik orang lain. Hak beragama dalam konteks hak asasi individu tidak dapat dipisahkan dari hak beragama dalam konteks hak asasi komunal yang bertujuan untuk mewujudkan kehidupan berbangsa dan bernegara dan demi terciptanya ketertiban masyarakat umum.

\section{DAFTAR PUSTAKA}

Al Khanif, 2010. Hukum dan Kebebasan beragama di Indonesia. Yogyakarta: LaksBang Mediatama;

al-Mawdûdî, Abu al A'la. 1993. "Human Rights, the West and Islam," dalam Tahir Mahmood (ed.), Human Rights in Islamic Law, New Delhi: Institute of Objective Studies;

Arliman S, Laurensius. "Penyelesaian Konflik Antar Umat Beragama (Studi Pada Komnas HAM Perwakilan Sumatera Barat". Padjadjaran Jurnal Ilmu Hukum. Vol. 2, No. Tahun 2015.

Arliman S. Laurensius. 2015. Komnas HAM dan Perlindungan Anak Pelaku Tindak Pidana, Yogyakarta: Deepublish;

51 Ibid.

52 Marzuki, Op.Cit., hlm. 201. 
65 Pena Justisia: Media Komunikasi dan Kajian Hukum

Vol. 17, No. 2, 2017

Asmarani, Nur. "Tori Hak Asasi Manusia (HAM)", Jurnal Hukum dan Masyarakat, Vol. 14, No. 1, Januari, 2015.

B.J. Habibie, 2006. Detik-Detik yang Menentukan: Jalan Panjang Indonesia Menuju Demokrasi. Jakarta: THC. Mandiri;

Bosko, Rafael Edy. Dkk. 2010. Kebebasan Beragama atau Berkeyakinan: Sejauk Mana? Sebuah Referensi tentang Prinsip-Prinsip dan Praktik, Yogyakarta: Kanisius;

Budiardjo, Miriam. "HAM dan Tap MPRS. No.XXV", Majalah Forum Keadilan, 9 April 2000.

Claude, RP. \& Wston, Burns H. 1992. Human Rights in the World Community, University of Pennsylvania Press, Philadelphia;

Cranston, Maurice. 1973. What are Human Rights? New York: Taplinger;

CST. Kansil dan Christine S.T. Kansil, 2003. Sekitar HAM Dewasa Ini. Jakarta: Djambatan;

Djafar, Wahyudi. Dkk. 2014. Memperkuat Perlindungan Hak Asasi Manusia di ASEAN, International NGO Forum on Indonesia Development (INFID), Desember 2014.

Donnelly, Jack. 2003. Universal Human Rights in Theory and Practice, Ithaca and London: Cornell University Press;

Halili, 2015, Hak Asasi Manusia: Dari Teori ke Pedagogi, Yogyakarta: Fakultas Ilmu Sosial Universitas Negeri;

HandBook Oak Fondation, Kewajiban Negara dalam Penanganan Kasus-Kasus Pelanggaran HAM dan Pelanggaran HAM yang Berat di Indonesia, Buku Panduan Mengukur Kewajiban Negara, Jakarta: The Commission for Disappearances and Victims of Violence, Mei 2014.

Harian Republika, "Solusi Kemelut Ahmadiyah", Jumat, 15 Agustus 2008.

Howard, Rhoda E. 2010. Penjelajahan Dalih Relativisme Budaya (terjemahan). Jakarta: PT. Pustaka Utama Grafiti;

Iskandar, Pranoto. 2010. Hukum HAM Internasional, Sebuah Pengantar Kontekstual. Malang: IMR Press;

Kemenkumhan RI, Ringkasan Putusan Mahkamah Konstitusi Nomor 140/PUU-VII/2009 tentang Pengujian UU No. 1 Tahun 1965 tentang Penyalahgunaan dan/atau Penodaan Agama, Media Publikasi Peraturan Perundang-Undangan dan Informasi Hukum, dapat diakses secara online di http://ditj enpp.kemenkumham.go.id/harmonisasirpp/62-data-perkembangan-litigasi /486-putusan-mahkamah-konstitusiterhadap-uu-pencegahan-penyalahguna an-danatau-penodaan-agama.html
Locke, John. 1964. The Second Treatise of Civil Government and a Letter Concerning Toleration, disunting oleh J.W. Gough, Blackwell: Oxford University Press;

Lubis, Todung Mulya. 1993. In search of Human Rights Legal-Political Dilemmas of Indonesia's New Order, 1966-1990, Jakarta: Gramedia;

Marzuki, "The Perspectives of the Constitutional Court on Human Rights". Jurnal Yudisial. Vol. 6 No. 3, Fakultas Hukum Universitas Islam Indonesia, Desember 2013.

Matondang, Ikhwan. Universalitas dan Relativitas HAM, Jurnal Miqot, Vol. XXXII, No. 2, Fakultas Ushuluddin IAIN Imam Bonjol, Juli-Desember 2008.

Muladi, Ahmad. 2014. Politik Hukum, Jakarta: Akademia Permata, 2014.

Munandar, Haris. 1994. Pembangunan Politik, Situasi Global, dan Hak Asasi di Indonesia, Jakarta: Gramedia Pustaka Utama;

Siregar, Parluhutan. "Etika Politik Global: Isu HakHak Asasi Manusia”. Jurnal Medan Agama, Vol. 6, No. 1, 2014,

Smith, Rhona K.M. 2010. Texts And Materials on International Human Right, Second edition, Routledge, London and Newyork;

Sodikin, "Hukum dan Hak Kebebasan Beragama", Jurnal Cita Hukum, Vol. I No. 2, 2013;

Soetandyo. "Hubungan Negara dan Masyarakat dalam Konteks Hak Asasi Manusia; Sebuah Tinjauan Historik dari Relativisme Budaya - Politik". Makalah disampaikan pada Seminar Pembangunan Hukum Nasional VIII diselenggarakan oleh BPHN DepKeh \& HAM. Denpasar, 2003.

Steiner, Henry J. dan Phillip Aston. 2000. International Human Rights in Context, Law, Politics, Moral. New York: Oxford University Press;

Sujatmoko, Andrey. Teori, Prinsip dan Kontroversi $H A M$, Training Metode Pendekatan Pengajaran, Penelitian, Penulisan Disertasi dan Pencarian Bahan Hukum HAM Bagi DosenDosen Hukum HAM, Sejarah Yogyakarta, 12- 3 Maret 2009.

Tore Lindholm, W. Cole Durham, Jr. Bahia G. Tahzib Lie. 2004. Facilitating Freedom of Religion or Belief: A Desbook, Leiden: Martinus Nijhoff Publisher;

United Nations, UN Charter, dapat diakses di www.un.org/en/charter-united-nations/

Wignjosoebroto, 